\title{
ЦУКРОВИЙ ДІАБЕТ 2 ТИПУ ТА ЗАХВОРЮВАННЯ ЩИТОПОДІБНОЇ ЗАЛОЗИ: ПОШУК СПІЛЬНИХ МЕХАНІЗМІВ
}

\section{Цукровий діабет 2 типу та захворювання щитоподібної залози: пошук спільних механізмів}

\section{В. А. Мусієнко, М. І. Марущак}

Тернопільський національний медичний університет імені І. Я. Горбачевського МОЗ України

Резюме. Цукровий діабет та захворювання щитоподібної залози (ЩЗ) - два найпоширеніші ендокринні порушення у клінічній практиці, оскільки порушення обміну речовин та тиреоїдних гормонів можуть впливати один на одного.

Мета дослідження - проаналізувати літературні джерела щодо поширеності цукрового діабету 2 типу, його коморбідності з захворюваннями щитоподібної залози та основні ланки патогенезу за умови їх поєднаного перебігу.

Матеріали і методи. У дослідженні опрацьовано наукові публікації за останнє десятиліття, які доступні у мережі «Інтернет», ключовими словами були «цукровий діабет 2 типу», «захворювання щитоподібної залози», «коморбідність», «патогенез».

Результати. Зв'язок між цукровим діабетом і порушенням роботи щитоподібної залози характеризується складною взаємодією. У ряді робіт повідомляється про поширеність дисфункції щитоподібної залози серед хворих на діабет у межах від 2,2 до $17 \%$. Однак у кількох дослідженнях спостерігається дуже висока поширеність диссрункції щитоподібної залози при діабеті 2 типу, тобто 31 та 46,5 \% відповідно. Високий чи низький рівень гормонів щитоподібної залози пов'язаний з периферичною резистентністю до інсуліну. Показано, що $T_{3}$ відіграє роль у захисті $\beta$-клітин підшлункової залози від апоптозу. Цукровий діабет порушує фрункцію щитоподібної залози, впливаючи як на гіпоталамічний контроль вироблення TTГ, так і на трансформацію $T_{4}$ до $T_{3}$ в перифреричній тканині. Тому пацієнтів із діабетом потрібно обстежувати на предмет дисфункції щитоподібної залози. Результати перехресного дослідження показали, що жіноча стать, сімейний анамнез захворювання щитоподібної залози та куріння можуть збільшити ризик виникнення гіпотиреозу у хворих на діабет. Інсулінорезистентність та компенсаторна гіперінсулінемія можуть брати участь у проліферації клітин ЩЗ та утворенні вузлів щЗ.

Висновоки. Зв'язок між фуункцією щз та щД $2 \epsilon$ двонаправленим та підлягає складним взаємодіям. Найпоширенішими розладами щЗ, що зустрічається серед хворих на ЦД 2, є субклінічний та клінічний гіпотиреоз, а також вузловий зоб.
Type 2 diabetes and thyroid disease: search for common mechanisms

\section{A. Musiienko, M. I. Marushchak}

I. Horbachevsky Ternopil National Medical University

e-mail: marushchak@tdmu.edu.ua

Summary. Diabetes mellitus and thyroid disease are the two most common endocrine disorders in clinical practice, as metabolic and thyroid hormone disorders can affect each other.

The aim of the study - to analyze the literature on the prevalence of type 2 diabetes, its comorbidity with thyroid diseases, and the main pathogenesis pathways, provided that they are combined.

Materials and Methods. The study looked at scientific publications over the last decade that are available on the Internet, with the key words "type 2 diabetes," "thyroid disease," "comorbidity," "pathogenesis."

Results. The relationship between diabetes and thyroid dysfunction is characterized by a complex interaction. A number of studies have reported the prevalence of thyroid dysfunction among patients with diabetes ranging from 2.2 to $17 \%$. However, several studies have shown a very high prevalence of thyroid dysfunction in type 2 diabetes, as $31 \%$ and $46.5 \%$, respectively. High or low levels of thyroid hormones are associated with peripheral insulin resistance. T3 has been shown to play a role in protecting pancreatic $\beta$-cells from apoptosis. Diabetes mellitus impairs thyroid function by affecting both the hypothalamic control of TSH production and the transformation of T4 to T3 in peripheral tissue. Therefore, patients with diabetes should be screened for thyroid dysfunction. Cross-sectional studies have shown that female sex, a family history of thyroid disease and smoking may increase the risk of hypothyroidism in patients with diabetes. Insulin resistance and compensatory hyperinsulinemia may be involved in thyroid cell proliferation and thyroid nodule formation.

Conclusions. The relationship between thyroid function and diabetes mellitus type 2 is bidirectional and subject to complex interactions. The most common thyroid disorders found in patients with diabetes mellitus are subclinical and clinical hypothyroidism, as well as nodular goiter. 
Ключові слова: цукровий діабет 2 типу; захворювання щитоподібної залози; гіпотиреоз; зоб.

\section{ВСТУП}

Цукровий діабет $є$ найпоширенішим ендокринним розладом у всьому світі [1]. За оцінками A. B. Kaiser et al., у 2018 р. у світі зареєстровано 500 млн випадків цукрового діабету 2 типу (ЦД 2), при цьому автори зазначають, що його поширеність буде збільшуватись до 2028 р., особливо в країнах із низьким рівнем доходу [2]. На даний час у всьому світі кожна 11 доросла людина хворіє на цукровий діабет, 90 \% 3 них мають цукровий діабет другого типу [1]. Більшість пацієнтів із цД 2 має хоча б одне ускладнення [3]. Відомо, що Цд 2 також збільшує ризик розвитку серцево-судинних захворювань [4] й раку [5], що є провідними причинами смертності цих пацієнтів. У цілому зростання поширеності цукрового діабету негативно впливає на численні фрізіологічні функції, на стан органів та систем організму таких пацієнтів [6]. Враховуючи те, що гормони щитоподібної залози (щЗ) забезпечують енергетичний гомеостаз та беруть участь у дії інсуліну та регуляції глюкози [7], а також ряд досліджень про високий рівень поширеності порушень щ3 у хворих на діабет [8, 9], актуальним $\epsilon$ дослідження спільних ланок патогенезу цих патологій.

Метою дослідження було проаналізувати літературні джерела щодо поширеності цукрового діабету 2 типу, його коморбідності з захворюваннями щитоподібної залози та основні ланки патогенезу за умови їх поєднаного перебігу.

\section{МАТЕРІАЛИ І МЕТОДИ}

У дослідженні опрацьовано наукові публікації за останнє десятиліття, які доступні у мережі «lнтернет», ключовими словами були «цукровий діабет 2 типу», «захворювання щитоподібної залози», «коморбідність», «патогенез».

\section{РЕЗУЛЬТАТИ ТА ОБГОВОРЕННЯ}

Цукровий діабет та захворювання ЩЗ - два найпоширеніші ендокринні порушення в клінічній практиці, оскільки порушення обміну речовин, інсуліну та тиреоїдних гормонів можуть впливати один на одного [10]. У ряді робіт повідомляється про поширеність диссрункції щитоподібної залози серед хворих на діабет у межах від 2,2 до 17 \% [11-13]. Однак у кількох дослідженнях спостерігається дуже висока поширеність дисфункції щз при діабеті 2 типу, тобто 31 та 46,5 \% відповідно [14,15]. Вплив розладу щз на діабет відомий з 1979 р. [16]. Розлади щз не лише погіршують метаболічний контроль, але й впливають на лікування діабету [17].
Key words: type 2 diabetes; thyroid disease; hypothyroidism; goiter.

Щитоподібна залоза - одна з найбільших ендокринних залоз в організмі. Гормони щ3 - це регуляторні гормони, які впливають на обмінні процеси в усьому організмі, а також відіграють життєво важливу роль у гомеостазі глюкози, контролюючи секрецію інсуліну та впливаючи на надходження глюкози в кров [18]. Тиреотропін-рилізинг-гормон (ТРГ) - це гормон, що секретується гіпоталамусом, регулює синтез та вивільнення тиреотропного гормону (ТТГ) із гіпофріза, який стимулює вироблення та секрецію тиреоїдних (трийодотиронін та тироксин) гормонів щитоподібною залозою. Через класичний цикл зворотного зв'язку тиреоїдні гормони гальмують вироблення ТРГ та ТТГ. У тканинах-мішенях дейодиназа типів 1 і 2 перетворює тироксин $\left(\mathrm{T}_{4}\right)$ в активний гормон - трийодотиронін $\left(\mathrm{T}_{3}\right)$, тоді як дейодиназа типу 3 перетворює тироксин в неактивний зворотний трийодотиронін.

Диссрункція щитоподібної залози включає гіпотиреоз, гіпертиреоз та дифузний вузловий зоб. Перші дві ендокринопатії викликає аутоімунний процес, і вони включаються до спектра аутоімунних захворювань щитоподібноїі залози. Знижене всмоктування глюкози з шлунково-кишкового тракту, що супроводжується тривалим накопиченням периореричної глюкози, глюконеогенез, зменшення викиду глюкози в печінці є ознаками гіпотиреозу та характеризується зниженням рівня сироваткових $T_{3}$ та $T_{4}$ із збільшенням рівня сироваткового ТТГ, отже, призводить до гіперглікемічного стану [19]. Це на відміну від пацієнтів із гіпертиреозом, коли збільшується вихід глюкози з печінки, що є головною причиною індукції гіперінсулінемії, глюкозної непереносимості та розвитку периферичної інсулінорезистентності, збільшення абсорбції глюкози в кишечнику. Толерантність до глюкози при тиреотоксикозі зумовлена підвищеним виробленням печінкової глюкози разом із регульованим глікогенолізом [20]. Також скорочується період напіввиведення інсуліну, швидше за все через збільшення швидкості деградації та посиленого вивільнення біологічно неактивних попередників інсуліну [21]. Спостерігається підвищення рівня сироваткових вільних $\mathrm{T}_{3}$ та $\mathrm{T}_{4}$, тоді як рівень ТТГ у сироватці крові значно знижується. Поширеність гіпертиреозу становить від 0,2 до 1,3 \% у країнах із достатнім споживанням йоду [22]. Метааналіз європейських досліджень оцінив середній показник поширеності 0,75 \% та рівень захворюваності 51 випадок на 100 000 на рік [23]. Загалом, захворюваність на гіпертиреоз залежить від споживання йоду населенням, причому більш високі показники гіпертиреозу виникають у країнах із дефріцитом йоду [24]. 
Високий чи низький рівень гормонів щитоподібної залози пов'язаний із периферичною резистентністю до інсуліну [24]. Показано, що $\mathrm{T}_{3}$ відіграє роль у захисті $\beta$-клітин підшлункової залози від апоптозу [25]. ЦД порушує фрункцію щитоподібної залози, впливаючи як на гіпоталамічний контроль вироблення ТТГ, так і на транссрормацію $\mathrm{T}_{4}$ до $\mathrm{T}_{3} \mathrm{y}$ периферичній тканині [26]. Тому пацієнтів із діабетом потрібно обстежувати на предмет дисфрункції щитоподібної залози. Підвищений рівень ТТГ у хворих на діабет може бути результатом прийому медикаментів, які пригнічують рівень вільного $\mathrm{T}_{4}$ [27]. Інша причина - інсулін, який підвищує рівень $\mathrm{T}_{4}$, пригнічуючи рівень $\mathrm{T}_{3}$, пригнічуючи печінкову конверсію $\mathrm{T}_{4}$ в $\mathrm{T}_{3}$. Також причиною можуть бути аутоімунні захворювання та поширеність тиреоїдних антитіл у хворих на ЦД 2 [28].

Деякі дослідження показали, що рівень циркуляції фрактора дисреренціації росту 15 (GDF-15) у пацієнтів із ЦД 2 був значно вищим [29] та пов'язаним із гіперплазією клітин при ЦД 2 [30]. Також GDF-15 пов'язаний із збільшенням ризику раку при ЦД 2 [30]. Оскільки GDF-15 володіє потенційною здатністю до активізації росту клітин, а його циркулюючі концентрації при діабеті 2 типу підвищені, логічно розглядати GDF-15 як перспективного кандидата для оцінки ризику диссрункції щЗ у хворих на ЦД 2. Результати деяких досліджень показали, що GDF-15 пов'язаний зі злоякісною фолікулярною неоплазією щитоподібної залози [31].

Кілька авторів повідомили про позитивні кореляції між десріцитом вітаміну D та диссрункцією ЩЗ серед пацієнтів із ЦД $2[32,33]$. Його вплив на захворювання щитоподібної залози широко висвітлюються в клінічній практиці $[32,34]$. Десріцит вітаміну D та ЦД 2 зазвичай визнаються ускладненням та ризиком захворювання щитоподібної залози. Хоча варто зазначити, що можливу роль дефіциту вітаміну D можна розглядати у патогенезі як ЦД, так і захворювання щЗ. Однак він також може бути вторинним для цих захворювань. Пероральні протидіабетичні препарати, а також терапевтичне обмеження дієти можуть впливати на рівень вітаміну D у пацієнтів із діабетом. Крім того дисфункція щитоподібної залози може також змінювати споживання вітаміну D, абсорбцію або метаболізм.

Дейодиназа 2 типу (D2) кодується геном DIO2 i каталізує перетворення $\mathrm{T}_{4}$ у біоактивний $\mathrm{T}_{3}$. Хоча точна роль експресії DIO2 та активності D2 у білій жировій тканині у сприянні патогенезу ЦД 2 залишається майже невідомою, останні дослідження показують потенційний вплив. Як полісреноли, так і жовчні кислоти посилюють експресію/активацію DIO2, покращують мітохондріальне дихання у білій жировій тканині та скелетних м'язах та посилюють втрату маси [35]. Крім того поліморфізми в
DIO2 були пов'язані з підвищеною резистентністю до інсуліну, ризиком розвитку ЦД 2 та поганим контролем глікемії [36]. На сьогодн було знайдено кілька поліморфізмів DIO2, які можуть впливати на рівень гормонів щитоподібної залози. Виявлено, що часто зустрічається поліморфрізм Thr92Ala, що пов'язують 3 ожирінням та інсулінорезистентністю. Активність D2 виявилася зниженою серед гомозиготних варіантів Ala92Ala порівняно $3 \mathrm{Thr} / \mathrm{Thr}$ та гетерозиготними генотипами Thr/Ala [37]. Поліморфрізм DIO2 Thr92Ala також був пов'язаний із підвищеним ризиком остеоартриту, гіпертонічної хвороби, дисрузним токсичним зобом, змінами когнітивної сорери, пов'язаними з дефріцитом йоду, а також зменшення кісткової маси [37]. Цікаво, що більшість цих асоціацій не залежать від рівня тиреоїдних гормонів у сироватці крові, що підкреслює важливість місцевої регуляції тиреоїдних гормонів у периферичних тканинах.

Гіпотиреоз. Загальна поширеність гіпотиреозу в загальних скринінгових обстеженнях населення становила від 2,1 до 9,5 \% [10], тоді як вона становила від 5,7 до 25,3 \% у хворих на ЦД 2 [38, 39]. Пояснення мінливості поширеності гіпотиреозу в різних популяціях діабету може бути здійснено за допомогою декількох параметрів, таких, як адекватність споживання йоду, метаболічний синдром, кілька супутніх захворювань, які пов'язані із дисфункцією щитоподібної залози та в перспективі епідеміології - загальна поширеність діабету серед населення.

Гіпотиреоз часто $€$ результатом аутоімунного руйнування фолікулів щитоподібної залози за допомогою антитіл. Вік, стать та сімейний анамнез захворювання залози розглядаються як споріднені фрактори гіпотиреозу у хворих на ЦД 2 [39]. Однак асоціації між гіпотиреозом та курінням, рівнем ліпопротеїнів та тривалістю діабету $є$ непереконливими та конорліктними [40]. Результати перехресного дослідження показали, що жіноча стать, сімейний анамнез захворювання щитоподібної залози та куріння можуть збільшити ризик виникнення гіпотиреозу у хворих на діабет [41]. Giandalia et al. Також зауважили, що жінки з діабетом мали нижчий рівень вільного Т та більш високий рівень ТТГ у сироватці крові, порівняно з чоловіками, хворими на діабет [42]. Явний та субклінічний гіпотиреоз може призвести до порушення функції нирок через зменшення ШКФ, змін у роботі серця та судин, а також до порушення ренін-ангіотензинової системи [43]. Гіпотиреоз також асоціювався 3 неалкогольною жировою хворобою печінки, смертністю від раку, артритом та диссрункцією нирок, але причинність у цих ситуаціях суперечлива [44]. Крім того лікування гіпотиреозу може покращити чутливість до інсуліну [46]. Також деякі перспективні дослідження $[46,47]$ показали, що лікування 
левотироксином може значно знизити співвідношення альбуміну до креатиніну в сечі й має захисну дію на нирки у пацієнтів із діабетичною нефропатією. Навпаки, було встановлено, що пацієнти 3 поганим контролем глікемії мають високий ризик виникнення субклінічного гіпотиреозу [48], можливо, через стимулювальну дію більш високих рівнів лептину на вісь гіпоталамус-гіпофріз-щитоподібна залоза [45].

Субклінічний гіпотиреоз (СГ) визначається як безсимптомний стан, який характеризується високою сироватковою концентрацією ТТГ та нормальною сироватковою концентрацією $\mathrm{T}_{4}$. СГ часто не діагностується через його непомітні симптоми. Однак він являє собою легку недостатність щитоподібної залози і має несприятливі клінічні наслідки. СГ не є рідкісним ендокринним розладом, оскільки, як повідомляється, його поширеність варіювала від 4 до 10 \% [49]. Патогенез субклінічного гіпотиреозу пов'язаний з ендотеліальною диссрункцією, гіперліпідемією та атеросклерозом, які збільшують ризик серцево-судинних захворювань [49]. Зв'язок між СГ та ЦД 2 добре відомий і його поширеність при ЦД 2 коливався від 2,2 до $17 \%$ [49]. Близько 2-5 \% пацієнтів із субклінічним гіпотиреозом можуть прогресувати у явний гіпотиреоз за рік, якщо не лікуватись [10], та викликати несприятливі клінічні наслідки. В декількох дослідженнях було помічено зв'язок між СГ та ішемічною хворобою серця, хоча результати були суперечливими [50, 51]. Проте лише незначна частина з них була зосереджена на популяції із діабетом. На даний час існує не достатня кількість даних про взаємозв'язок СГ та мікроангіопатією як одним із ускладнень ЦД 2. Субклінічний гіпотиреоз середньої тяжкості пов'язаний з більш високим ризиком серцевої недостатності та інсульту в молоді [44]. Кілька клінічних досліджень $[52,53]$ повідомили, що субклінічний гіпотиреоз також пов'язаний 3 розвитком діабетичної нефропатії та мікроальбумінурії. Chubb et al. [54] продемонстрували, що антитіла до тиреопероксидази (АТПО) були незалежно пов'язані з СГ у пацієнтів із ЦД 2. Повідомляється також, що субклінічний гіпотиреоз пов'язаний із резистентністю до інсуліну [55].

Зоб. Поширеність ЦД 2 та вузлового зоба становить $61,8 \%$ у регіонах із легким та помірним дефріцитом йоду [57]. Основним етіологічним фракторомпопередньогодослідженнябуларезистентність до інсуліну [58]. Етіологічні фрактори, такі, як дефіцит йоду, куріння та генетика, є основними причинами орормування вузлового зобу щЗ. Ожиріння також розглядають як фрактор, що пов'язаний із більшим об'ємом ЩЗ та розвитком вузлів Щ3 [56]. Останні дослідження говорять про важливу роль інсулінорезистентності у фрормуванні вузлового зоба [59]. Добре відомо, що інсулін та інсулінопо- дібний фрактор росту (IGFs) надають мітогенну дію на клітинні культури, збільшуючи проліферацію клітин. Показано, що сигнальні шляхи IGF-1 та IGF-2/інсуліну модулюють регуляцію та експресію генів щ3 [59]. Таким чином, інсулінорезистентність та компенсаторна гіперінсулінемія можуть брати участь у проліферації клітин щЗ та утворенні вузлів щ3 [60]. Є дані, що описують більший об'єм щ3 та велику частоту вузлового зоба у пацієнтів із гіперінсулінемією та метаболічним синдромом [60]. Добре відомо, що метаболічний синдром частіше проявляється у пацієнтів $з$ ожирінням. Рівень ТТГ був пов' заний з індексом маси тіла у дослідженні Anil et al., що також виявило більш високі рівні ТТГ у пацієнтів із ЦД 2, ніж у контрольній групі та у пацієнтів із предіабетом [58]. Більш висока поширеність вузлового зоба щитоподібної залози у пацієнтів із ЦД 2 може бути пояснена такою ж більшою поширеністю ожиріння у цих пацієнтів щодо осіб із цукровим діабетом 1 типу. У будь-якому випадку, резистентність до інсуліну - не єдина можлива причина утворення вузлів щ3 [59].

Рак Щ3. Рак щитоподібної залози є найпоширенішим злоякісним захворюванням ендокринної системи у світі в жінок [61]. До найчастіших типів відносяться папілярні, фролікулярні та диференційовані карциноми щитоподібної залози [62]. Американське товариство раку повідомило про захворюваність на рак щитоподібної залози 1 на 10000 у США [61]. Попередні метааналізи ілюстрували вплив численних фракторів на ризик виникнення раку щ3 [63-65], тоді як вплив діабету менш вивчений та з обмеженими і непереконливими результатами. У кількох когортних дослідженнях зазначено, що хворі на ЦД 2 можливо мали підвищений ризик розвитку раку щ3 [66], тоді як інші дослідження не знаходили взаємозв'язку [61]. Підвищений ризик раку щЗ у діабетиків може бути пов'язаний з декількома фракторами, серед яких підвищений рівень глікозильованого гемоглобіну та тригліцеридів, метаболічний синдром, ожиріння, порушення харчування та спосіб життя [67]. Пацієнти 3 ожирінням мали ризик розвитку діабету в 10 разів вище, а ожиріння було пов'язане з підвищеним ризиком раку щ3 [46].

Що стосується можливого впливу медикаментів, які застосовуються для лікування ЦД 2 із захворюваністю на рак щЗ, останні дослідження показали, що меторормін полегшує апоптоз клітин раку щитоподібної залози і що вживання його пацієнтами з ЦД 2 може знизити ризик раку щитоподібної залози [68]. Також терапія меторорміном знижує рівень ТТГ у хворих на ЦД та гіпотиреоз можливо завдяки його дії в гіпоталамусі [69]. Існують дослідження, які підтверджують, що метформін має супресивну дію на рівні ТТГ, не втручаючись у рівень гормонів щитоподібної залози. Цей 
еорект не залежить від аутоімунних процесів у щз та лікування тироксином [69]. Меторормін має нейтральну дію на зоб, тоді як інсулінотерапія, можливо, виконує захисну роль проти утворення вузлового зоба. В одному дослідженні, проведеному 3 пацієнтами з цукровим діабетом 1 типу, виявляли нижчу частоту захворювання вузлів щитоподібної залози порівняно з хворими на ЦД 2 [70].

\section{ВИСНОВКИ}

Зв'язок між фрункцією щЗ та ЦД 2 є двонаправленим та підлягає складним взаємодіям. Найпо-

\section{СПИСОК ЛІТЕРАТУРИ}

1. Zheng Y. Global aetiology and epidemiology of type 2 diabetes mellitus and its complications / Y. Zheng, S. H. Ley, F. B. Hu // Nat. Rev. Endocrinol. - 2018. - No. 14 (2). - P. 88-98.

2. Kaiser A. Global prevalence of type 2 diabetes over the next ten years (2018-2028) / A. Kaiser, N. Zhang, W. Der Pluijm // Diabetes. - 2018. - No. 67 (1) - P. 202-LB.

3. Prevalence of diagnosed type 1 and type 2 diabetes among US adults in 2016 and 2017: population based study / G. Xu, B. Liu, Y. Sun [et al.] // BMJ. - 2018. - No. 362. P. 1497.

4. Diabetes and cardiovascular disease: a statement for healthcare professionals from the American Heart Association / S. Grundy, I. Benjamin, G. Burke [et al.] // Circulation. - 1999. - No. 100 (10). - P. 1134-1146.

5. Cancer risk among people with type 1 and type 2 diabetes: disentangling true associations, detection bias, and reverse causation / J. Harding, J. Shaw, A. Peeters [et al.] // Diabetes Care. $\neg-2015$. - No. 38 (2). - P. 264-270.

6. Prevalence of type 2 diabetes mellitus among men in the Middle East: A retrospective study / S. Meo, S. Sheikh, K. Sattar [et al.] // Am. J. Men's Health. - 2019. - No. 13 (3) - P.1557988319848577.

7. Thyroid function in patients with type 2 diabetes mellitus and diabetic nephropathy: A single center study I W. Zhao, X. Li, X. Liu [et al.] // J. Thyroid Res. - 2018. 2018. - P. 9507028.

8. Kalra S. Thyroid disorders and diabetes / S. Kalra // J. Pak. Med. Assoc. - 2014. - No. 64 (8). - P. 966-968.

9. Distiller L. A. Type 2 diabetes mellitus and hypothyroidism: the possible influence of metformin therapy / L. A. Distiller, E. S. Polakow, B. I. Joffe // Diabet. Med. 2014. - No. 31 (2). - P. 172-175.

10. The prevalence and determinants of hypothyroidism in hospitalized patients with type 2 diabetes mellitus / F. Song, C. Bao, M. Deng [et al.] // Endocrine. - 2017. No. 55 (1). - P. 179-185.

11. Subclinical hypothyroidism and type 2 diabetes: $A$ systematic review and meta-analysis / C. Han, X. He, X. Xia [et al.] // PLoS One. - 2015. - No. 10 (8):e0135233.

12. Thyroid dysfunction in type 2 diabetes mellitus patients/I. Subekti, L. Pramono, E. Dewiasty, D. Harbuwono // Acta Med. Indones. - 2017. - No. 49 (4). - P. 314-323.

13. Vinu V. Evaluation of thyroid dysfunction among type II diabetic patients / V. Vinu, P. Chitnis, V. Gupta // IJPBS. - 2012. - No. 2 (4). - P. 150-155. ширенішими розладами щ3, що зустрічається серед хворих на ЦД 2, є субклінічний та клінічний гіпотиреоз. Результати перехресного дослідження показали, що жіноча стать, сімейний анамнез захворювання щитоподібної залози та куріння можуть збільшити ризик виникнення гіпотиреозу у хворих на діабет.

Вузловий зоб є другим за частотою коморбідного перебігу з ЦД 2. Інсулінорезистентність та компенсаторна гіперінсулінемія можуть брати участь у проліферації клітин щЗ та утворенні вузлів щз.

14. Evaluation of thyroid hormones level in patients with type 2 diabetes mellitus as compared to normal individuals in Nepal / A. Acharya, P. Shah, E. Chitkara, S. Shrestha // IJHSR. - 2017. - No. 7 (1). - P. 79-85.

15. Thyroid dysfunction in patients with type 2 diabetes mellitus in Jordan / A. Radaideh, M. Nusier, F. Amari [et al.] // Saudi Med. J. - 2004. - No. 25 (8). - P. 1046-1050.

16. Feely J. Screening for thyroid dysfunction in diabetics. / J. Feely, T. Isles // Br. Med. J. - 1979. - No. 1 (6179) - P. 1678.

17. Evaluation of hypothyroidism as a complication in type II diabetes mellitus / R. Swami, N. Kumar, K. Srinivasa [et al.] // J. Biomed. Res. - 2012. - No. 23(2). - P. 170-172.

18. Effect of thyroid hormones on hyperglycaemia in patients with type 2 diabetes mellitus / S. Mushtaq, S. Ishaq, I. Shabir [et al.] // Carib. J. Sci. Tech. -2017. - No. 5 - P. 18-24.

19. Wang $C$. The relationship between type 2 diabetes mellitus and related thyroid diseases / C. Wang // J. Diabetes Res. - 2013. - No. 2013 - P. 390534.

20. Brenta G. Potential therapeutic applications of thyroid hormone analogs / G. Brenta, S. Danzi, I. Klein // Nat. Clin. Pract. Endocrinol. Metab. - 2007. - No. 3 (9). P. 632-640.

21. Association between glycemic status and thyroid dysfunction in patients with type 2 diabetes mellitus / S. Ogbonna, I. Ezeani, C. Okafor, S. Chinenye // Diabetes Metab. Syndr. Obes. - 2019. - No. 12. - P. 1113-1122.

22. Global epidemiology of hyperthyroidism and hypothyroidism / P. N. Taylor, D. Albrecht, A. Scholz [et al.] // Nat. Rev. Endocrinol. - 2018. - No. 14 (5). - P. 301-316.

23. The incidence and prevalence of thyroid dysfunction in Europe: a meta-analysis / A. Garmendia Madariaga, S. Santos Palacios, F. Guillen-Grima, J. C. Galofre // J. Clin. Endocrinol. Metab. - 2014. - No. 99 (3). - P. 923-931.

24. Thyroid hormones are positively associated with insulin resistance early in the development of type 2 diabetes / V. Lambadiari, P. Mitrou, E. Maratou [et al.] // Endocrine. - 2011. - No. 39 (1). - P. 28-32.

25. 3,5,3'-triiodothyronine (T3) is a survival factor for pancreatic beta-cells undergoing apoptosis / C. Verga Falzacappa, L. Panacchia, B. Bucci [et al.] // J. Cell Physiol. - 2006. - No. 206 (2). - P. 309-321.

26. Thyroid disorders in type 2 diabetes mellitus / V. Nandyala, P. Gandiah, P. Sivarajappa [et al.] // International Journal of Recent Trends in Science and Technology. - 2013. - No. 9 (2). - P. 250-255. 
27. Carreras-González G. Thyroid autoimmunity at onset of type 1 diabetes as a predictor of thyroid dysfunction / G. Carreras-González, A. Pérez // Response to Warren and Frier. - 2007. - No. 30 (11) - e121-e.

28. Elmenshawi I. Prevalence of thyroid dysfunction in diabetic patients / I. Elmenshawi // Journal of Diabetes and Metabolic Disorders. - 2017. - No. 4 (2).

29. Dominguez-Rodriguez A. Usefulness of growth differentiation factor-15 levels to predict diabetic cardiomyopathy in asymptomatic patients with type 2 diabetes mellitus / A. Dominguez-Rodriguez, P. AbreuGonzalez, P. Avanzas // Am. J. Cardiol. - 2014. No. 114 (6). - P. 890-894.

30. GDF-15 Is associated with cancer incidence in patients with type 2 diabetes / N. Pavo, R. Wurm, S. Neuhold [et al.] // Clin. Chem. - 2016. - No. 62 (12). - P. 1612-1620.

31. Elevated serum growth differentiation factor 15 levels are associated with thyroid nodules in type 2 diabetes aged over 60 years / H. Zhang, W. Zhang, X. Tu [et al.] // Oncotarget. - 2017. - No. 8 (25). - P. 41379-41386.

32. Mazokopakis E. E. Hashimoto's autoimmune thyroiditis and vitamin D deficiency. Current aspects / E. Mazokopakis, D. Kotsiris // Hell J. Nucl. Med. - 2014. No. 17 (1). - P. 37-40.

33. Kim D. Low vitamin D status is associated with hypothyroid Hashimoto's thyroiditis / D. Kim // Hormones (Athens). - 2016. - No. 15 (3). - P. 385-393.

34. Diabetes and thyroid cancer risk in the National Institutes of Health-AARP Diet and Health Study / B. Aschebrook-Kilfoy, M. Sabra, A. Brenner [et al.] // Thyroid. - 2011. - No. 21 (9). - P. 957-963.

35. Adipocyte DIO2 expression increases in human obesity but is not related to systemic insulin sensitivity / D. Bradley, J. Liu, A. Blaszczak [et al.] // J. Diabetes Res. 2018. - No. 2018. - P. 2464652.

36. The type 2 deiodinase Thr92Ala polymorphism is associated with worse glycemic control in patients with type 2 diabetes mellitus: A systematic review and meta-analysis / X. Zhang, J. Sun, W. Han [et al.] // J. Diabetes Res. -2016. - No. 2016 - P. 5928726.

37. Yalakanti D. Association of type II 5' monodeiodinase Thr92Ala single nucleotide gene polymorphism and circulating thyroid hormones among type 2 diabetes mellitus patients / D. Yalakanti, P. B. Dolia // Indian J. Clin. Biochem. - 2016. - No. 31 (2). - P. 152-161.

38. Expression of CagL from Helicobacter pylori and preliminary study of its biological function / $\mathrm{H}$. Wang, S. Huang, J. Zhao [et al.] // Indian J. Microbiol. - 2013. No. 53 (1). - P. 36-40.

39. Risk factors for thyroid dysfunction among type 2 diabetic patients in a highly diabetes mellitus prevalent society / M. Al-Geffari, N. A. Ahmad, A. H. Al-Sharqawi [et al.] // Int. J. Endocrinol. - 2013. - No. 2013. - P. 417920.

40. Prevalence of thyroid dysfunction among greek type 2 diabetic patients attending an outpatient clinic / A. Papazafiropoulou, A. Sotiropoulos, A. Kokolaki [et al.] // J. Clin. Med. Res. - 2010. - No. 2 (2). - P. 75-78.

41. Thyroid dysfunction and associated risk factors among Nepalese diabetes mellitus patients / S. Khatiwada, R. Kc, S. K. Sah [et al.] // Int. J. Endocrinol. - 2015. No. 2015 - P. 570198.

42. Influence of high-normal serum TSH levels on major cardiovascular risk factors and Visceral Adiposity
Index in euthyroid type 2 diabetic subjects / A. Giandalia, G. T. Russo, E. L. Romeo [et al.] // Endocrine. - 2014. No. 47 (1). - P. 152-160.

43. Association between thyroid function and diabetic nephropathy in euthyroid subjects with type 2 diabetes mellitus: a cross-sectional study in China / J. Wang, H. Li, M. Tan [et al.] // Oncotarget. -2019. - No. 10 (2). - P. 88-97.

44. Hypothyroidism / L. Chaker, A. C. Bianco, J. Jonklaas, R. P. Peeters // Lancet. - 2017. - No. 390 (10101). - P. 1550-1562.

45. Thyroid-stimulating hormone levels in the normal range and incident type 2 diabetes mellitus / T. I. de Vries, L. J. Kappelle, Y. van der Graaf [et al.] // Acta. Diabetol. 2019. - No. 56 (4). - P. 431-440.

46. Can levothyroxine treatment reduce urinary albumin excretion rate in patients with early type 2 diabetic nephropathy and subclinical hypothyroidism? A randomized double-blind and placebo-controlled study / P. Liu, R. Liu, X. Chen [et al.] // Curr. Med. Res. Opin. - 2015. - No. 31 (12). - P. 2233-2240.

47. Thyroid hormone replacement therapy attenuates the decline of renal function in chronic kidney disease patients with subclinical hypothyroidism / D. H. Shin, M. J. Lee, H. S. Lee [et al.] // Thyroid. - 2013. - No. 23(6) - P. 654-661.

48. Poor glycemic control is associated with the risk of subclinical hypothyroidism in patients with type 2 diabetes mellitus / J. H. Cho, H. J. Kim, J. H. Lee [et al.] // Korean J. Intern. Med. - 2016. - No. 31 (4). - P. 703-711.

49. Association of thyroid-stimulating hormone levels with microvascular complications in type 2 diabetes patients / Q. Qi, Q. M. Zhang, C. J. Li [et al.] // Med. Sci. Monit. 2017. - No. 23. - P. 2715-2720.

50. Thyroid status, cardiovascular risk, and mortality in older adults / A. R. Cappola, L. P. Fried, A. M. Arnold [et al.] // JAMA. - 2006. - No. 295 (9). - P. 1033-1041.

51. Mohamed G. A. Subclinical hypothyroidism ups the risk of vascular complications in type 2 diabetes / G. A. Mohamed, A. M. Elsayed // Alexandria Journal of Medicine. - 2017. - No. 53 (3). - P. 285-288.

52. Subclinical hypothyroidism and the associations with macrovascular complications and chronic kidney disease in patients with type 2 diabetes / F. Jia, J. Tian, F. Deng [et al.] // Diabet. Med. - 2015. - No. 32 (8). P. 1097-1103.

53. Response: subclinical hypothyroidism is independently associated with microalbuminuria in a cohort of prediabetic egyptian adults (diabetes metab j 2013;37:450-7) / M. M. El-Eshmawy, H. A. Abd El-Hafez, W. O. El Shabrawy, I. A. Abdel Aal // Diabetes Metab. J. 2014. - No. 38 (1). - P. 85-86.

54. Prevalence and progression of subclinical hypothyroidism in women with type 2 diabetes: the Fremantle Diabetes Study / S. A. Chubb, W. A. Davis, Z. Inman, T. M. Davis // Clin. Endocrinol. (Oxf). - 2005. No. 62 (4). - P. 480-486.

55. Thyroid signaling, insulin resistance, and 2 diabetes mellitus: A Mendelian Randomization Study / M. M. Bos, R. A. J. Smit, S. Trompet [et al.] // J. Clin. Endocrinol. Metab. - 2017. - No. 102 (6). - P. 1960-1970.

56. Association of obesity and diabetes with thyroid nodules / S. Buscemi, F. M. Massenti, S. Vasto [et al.] // Endocrine. - 2018. - No. 60 (2). - P. 339-347. 
57. Iwen K. A. Thyroid hormones and the metabolic syndrome / K. A. Iwen, E. Schroder, G. Brabant // Eur. Thyroid J. - 2013. - No. 2 (2). - P. 83-92.

58. Impaired glucose metabolism is a risk factor for increased thyroid volume and nodule prevalence in a mild-to-moderate iodine deficient area / C. Anil, A. Akkurt, S. Ayturk [et al.] // Metabolism. - 2013. - No. 62 (7). P. 970-975.

59. Thyroid dysfunction among Greek patients with type 1 and type 2 diabetes mellitus as a disregarded comorbidity / M. E. Barmpari, M. Kokkorou, A. Micheli [et al.] // J. Diabetes Res. - 2017. - No. 2017. - P. 6505814.

60. Insulin resistance in nodular thyroid disease / H. Y. Yasar, O. Ertugrul, B. Ertugrul [et al.] // Endocr. Res. 2011. - No. 36 (4). - P. 167-174.

61. Li H. Association of diabetes mellitus with thyroid cancer risk: A meta-analysis of cohort studies / H. Li, J. Qian // Medicine (Baltimore). - 2017. - No. 96 (47) - P. e8230.

62. Xing M. Molecular pathogenesis and mechanisms of thyroid cancer / M. Xing // Nat. Rev. Cancer. - 2013. No. 13 (3). - P.184-199.

63. An overall and dose-response meta-analysis for thyrotropin and thyroid cancer risk by histological type / N. Hu, Z. M. Li, J. F. Liu [et al.] // Oncotarget. - 2016. No. 7 (30) - P. 47750-47759.

\section{REFERENCES}

1. Zheng $\mathrm{Y}$, Ley $\mathrm{SH}$, Hu FB. Global aetiology and epidemiology of type 2 diabetes mellitus and its complications. Nat Rev Endocrinol. 2018;14(2): 88-98.

2. Kaiser A, Zhang N, Der Pluijm W. Global prevalence of type 2 diabetes over the next ten years (2018-2028). Diabetes. 2018;67(Supplement 1): 202-LB.

3. Xu G, Liu B, Sun Y, Du Y, Snetselaar LG, Hu FB, et al. Prevalence of diagnosed type 1 and type 2 diabetes among US adults in 2016 and 2017: population based study. BMJ. 2018;362: k1497.

4. Grundy SM, Benjamin IJ, Burke GL, Chait A, Eckel RH, Howard BV, et al. Diabetes and cardiovascular disease: a statement for healthcare professionals from the American Heart Association. Circulation. 1999;100(10): 1134-46.

5. Harding JL, Shaw JE, Peeters A, Cartensen B, Magliano DJ. Cancer risk among people with type 1 and type 2 diabetes: disentangling true associations, detection bias, and reverse causation. Diabetes Care. 2015;38(2): 264-70.

6. Meo SA, Sheikh SA, Sattar K, Akram A, Hassan A, Meo AS, et al. Prevalence of type 2 diabetes mellitus among men in the Middle East: A retrospective study. Am J Mens Health. 2019;13(3): 1557988319848577.

7. Zhao W, Li X, Liu X, Lu L, Gao Z. Thyroid function in patients with type 2 diabetes mellitus and diabetic nephropathy: A Single Center Study. J Thyroid Res. 2018;2018: 9507028.

8. Kalra S. Thyroid disorders and diabetes. J Pak Med Assoc. 2014;64(8): 966-8.

9. Distiller LA, Polakow ES, Joffe BI. Type 2 diabetes mellitus and hypothyroidism: the possible influence of metformin therapy. Diabet Med. 2014;31(2): 172-5.

10. Song F, Bao C, Deng M, Xu H, Fan M, Paillard-Borg $\mathrm{S}$, et al. The prevalence and determinants of hypothyroidism
64. Hypertension, serum lipids and cancer risk: A review of epidemiological evidence / R. Radisauskas, I. Kuzmickiene, E. Milinaviciene, R. Everatt // Medicina (Kaunas). - 2016. - No. 52 (2). - P. 89-98.

65. Risk factors for central lymph node metastasis in CNO papillary thyroid carcinoma: A systematic review and meta-analysis / W. Sun, X. Lan, H. Zhang [et al.] // PLoS One. - 2015. - No. 10 (10). - P. e0139021.

66. Modest increase in risk of specific types of cancer types in type 2 diabetes mellitus patients / S. F. Lo, S. N. Chang, C. H. Muo [et al.] // Int. J. Cancer. - 2013. No. 132 (1). - P. 182-188.

67. Low vitamin $D$ deficiency associated with thyroid disease among type 2 diabetic mellitus patients / A. Bener, Y. Ozdenkaya, A. Al-Hamaq [et al.] // J. Clin. Med. Res. 2018. - No. 10 (9). - P. 707-714.

68. The association between type 2 diabetes mellitus and thyroid cancer / Y. G. Seo, H. C. Choi, A. R. An [et al.] // J. Diabetes Res. - 2017. - No. 2017. - P. 5850879.

69. Pappa T. Metformin and thyroid: an update / T. Pappa, M. Alevizaki // Eur. Thyroid J. - 2013. - No. 2 (1). P. 22-28.

70. Diez J. J. An analysis of the relative risk for goitre in euthyroid patients with type 2 diabetes / J. J. Diez, P. Iglesias // Clin. Endocrinol. (Oxf). - 2014. - No. 80 (3). - P. 356-361.

in hospitalized patients with type 2 diabetes mellitus. Endocrine. 2017;55(1): 179-85.

11. Han C, He X, Xia X, Li Y, Shi X, Shan Z, et al. Subclinical hypothyroidism and type 2 diabetes: a systematic review and meta-Analysis. PLoS One. 2015;10(8) e0135233.

12. Subekti I, Pramono LA, Dewiasty E, Harbuwono DS. Thyroid dysfunction in type 2 diabetes mellitus patients. Acta Med Indones. 2017;49(4): 314-23.

13. Vinu Vij, Pallavi Chitnis, Vijay Kumar Gupta. Evaluation of thyroid dysfunction among type II diabetic patients. IJPBS. 2012;2(4): 150-55.

14. Acharya, A., Shah, P., Chitkara, E., \& Shrestha, S. Evaluation of thyroid hormones level in patients with type 2 diabetes mellitus as compared to normal individuals in Nepal. IJHSR. 2017;7(1): 79-85.

15. Radaideh AR, Nusier MK, Amari FL, Bateiha AE, El-Khateeb MS, Naser AS, et al. Thyroid dysfunction in patients with type 2 diabetes mellitus in Jordan. Saudi Med J. 2004;25(8): 1046-50.

16. Feely J, Isles TE. Screening for thyroid dysfunction in diabetics. Br Med J. 1979;1(6179): 1678.

17. Swami RM, Kumar N, Srinivasa K, Manjunath GN, Byrav PDS, Venkatesh G. Evaluation of hypothyroidism as a complication in type II diabetes mellitus. J Biomed Res. 2012;23(2): 170-2.

18. Mushtaq S, Ishaq S, Shabir I, Rashid M, Pratap A, Bhat $A$, et al. Effect of thyroid hormones on hyperglycaemia in patients with type 2 diabetes mellitus. Carib J Sci Tech. 2017;5: 18-24.

19. Wang $C$. The relationship between type 2 diabetes mellitus and related thyroid diseases. J Diabetes Res. 2013;2013: 390534.

20. Brenta G, Danzi S, Klein I. Potential therapeutic 
applications of thyroid hormone analogs. Nat Clin Pract Endocrinol Metab. 2007;3(9): 632-40.

21. Ogbonna SU, Ezeani IU, Okafor $\mathrm{Cl}$, Chinenye S. Association between glycemic status and thyroid dysfunction in patients with type 2 diabetes mellitus. Diabetes Metab Syndr Obes. 2019;12: 1113-22.

22. Taylor PN, Albrecht D, Scholz A, Gutierrez-Buey G, Lazarus JH, Dayan CM, et al. Global epidemiology of hyperthyroidism and hypothyroidism. Nat Rev Endocrinol. 2018;14(5): 301-16.

23. Garmendia Madariaga A, Santos Palacios S, Guillen-Grima F, Galofre JC. The incidence and prevalence of thyroid dysfunction in Europe: a meta-analysis. J Clin Endocrinol Metab. 2014;99(3): 923-31.

24. Lambadiari V, Mitrou $P$, Maratou E, Raptis AE, Tountas N, Raptis SA, et al. Thyroid hormones are positively associated with insulin resistance early in the development of type 2 diabetes. Endocrine. 2011;39(1): 28-32.

25. Verga Falzacappa C, Panacchia L, Bucci B, Stigliano A, Cavallo MG, Brunetti E, et al. 3,5,3'-triiodothyronine (T3) is a survival factor for pancreatic beta-cells undergoing apoptosis. J Cell Physiol. 2006;206(2): 309-21.

26. Nandyala V, Gandiah P, Sivarajappa P, Indira G, Annavaram N. Thyroid disorders in type 2 diabetes mellitus. International Journal of Recent Trends in Science and Technology. 2013;9(2): 250-5.

27. Carreras-González G, Pérez A. Thyroid autoimmunity at onset of type 1 diabetes as a predictor of thyroid dysfunction. Response to Warren and Frier. 2007;30(11): e121-e.

28. Elmenshawi I. Prevalence of thyroid dysfunction in diabetic patients. Journal of Diabetes and Metabolic Disorders. 2017;4(2).

29. Dominguez-Rodriguez A, Abreu-Gonzalez $P$, Avanzas P. Usefulness of growth differentiation factor-15 levels to predict diabetic cardiomyopathy in asymptomatic patients with type 2 diabetes mellitus. Am J Cardiol. 2014;114(6): 890-4.

30. Pavo N, Wurm R, Neuhold S, Adlbrecht C, Vila G, Strunk G, et al. GDF-15 Is associated with cancer incidence in patients with type 2 diabetes. Clin Chem. 2016;62(12): 1612-20.

31. Zhang $\mathrm{H}$, Zhang $\mathrm{W}, \mathrm{Tu} \mathrm{X}$, Niu $\mathrm{Y}$, Li X, Qin L, et al. Elevated serum growth differentiation factor 15 levels are associated with thyroid nodules in type 2 diabetes aged over 60 years. Oncotarget. 2017;8(25): 41379-86.

32. Mazokopakis EE, Kotsiris DA. Hashimoto's autoimmune thyroiditis and vitamin D deficiency. Current aspects. Hell J Nucl Med. 2014;17(1): 37-40.

33. Kim D. Low vitamin D status is associated with hypothyroid Hashimoto's thyroiditis. Hormones (Athens). 2016;15(3): 385-93.

34. Aschebrook-Kilfoy B, Sabra MM, Brenner A, Moore SC, Ron E, Schatzkin A, et al. Diabetes and thyroid cancer risk in the National Institutes of Health-AARP Diet and Health Study. Thyroid. 2011;21(9): 957-63.

35. Bradley D, Liu J, Blaszczak A, Wright V, Jalilvand A, Needleman B, et al. Adipocyte DIO2 expression increases in human obesity but is not related to systemic insulin sensitivity. J Diabetes Res. 2018;2018: 2464652.

36. Zhang X, Sun J, Han W, Jiang Y, Peng S, Shan Z, et al. The type 2 Deiodinase Thr92Ala polymorphism is associated with worse glycemic control in patients with type
2 diabetes mellitus: A systematic review and meta-analysis. J Diabetes Res. 2016;2016: 5928726.

37. Yalakanti D, Dolia PB. Association of type II 5' Monodeiodinase Thr92Ala single nucleotide gene polymorphism and circulating thyroid hormones among type 2 diabetes mellitus patients. Indian J Clin Biochem. 2016;31(2): 152-61.

38. Wang H, Huang S, Zhao J, Han J, Guan X, Shao S. Expression of CagL from Helicobacter pylori and preliminary study of its biological function. Indian J Microbiol. 2013;53(1): 36-40.

39. Al-Geffari M, Ahmad NA, Al-Sharqawi AH, Youssef AM, Alnaqeb D, Al-Rubeaan K. Risk factors for thyroid dysfunction among type 2 diabetic patients in a highly diabetes mellitus prevalent society. Int $\mathrm{J}$ Endocrinol. 2013;2013: 417920.

40. Papazafiropoulou A, Sotiropoulos A, Kokolaki A, Kardara M, Stamataki P, Pappas S. Prevalence of thyroid dysfunction among greek type 2 diabetic patients attending an outpatient clinic. J Clin Med Res. 2010;2(2): 75-8.

41. Khatiwada S, Kc R, Sah SK, Khan SA, Chaudhari RK, Baral N, et al. Thyroid Dysfunction and Associated Risk Factors among Nepalese Diabetes Mellitus Patients. Int J Endocrinol. 2015;2015: 570198.

42. Giandalia A, Russo GT, Romeo EL, Alibrandi A, Villari $P$, Mirto AA, et al. Influence of high-normal serum TSH levels on major cardiovascular risk factors and Visceral Adiposity Index in euthyroid type 2 diabetic subjects. Endocrine. 2014;47(1): 152-60.

43. Wang J, Li H, Tan M, Gao G, Zhang Y, Ding B, et al. Association between thyroid function and diabetic nephropathy in euthyroid subjects with type 2 diabetes mellitus: a cross-sectional study in China. Oncotarget. 2019;10(2): 88-97.

44. Chaker L, Bianco AC, Jonklaas J, Peeters RP. Hypothyroidism. Lancet. 2017;390(10101): 1550-62.

45. de Vries TI, Kappelle LJ, van der Graaf Y, de Valk $\mathrm{HW}$, de Borst GJ, Nathoe HM, et al. Thyroid-stimulating hormone levels in the normal range and incident type 2 diabetes mellitus. Acta Diabetol. 2019;56(4): 431-40.

46. Liu P, Liu R, Chen X, Chen Y, Wang D, Zhang F, et al. Can levothyroxine treatment reduce urinary albumin excretion rate in patients with early type 2 diabetic nephropathy and subclinical hypothyroidism? A randomized double-blind and placebo-controlled study. Curr Med Res Opin. 2015;31(12): 2233-40.

47. Shin $\mathrm{DH}$, Lee MJ, Lee HS, Oh HJ, Ko KI, Kim CH, et al. Thyroid hormone replacement therapy attenuates the decline of renal function in chronic kidney disease patients with subclinical hypothyroidism. Thyroid. 2013;23(6): 65461.

48. Cho JH, Kim HJ, Lee JH, Park IR, Moon JS, Yoon $\mathrm{JS}$, et al. Poor glycemic control is associated with the risk of subclinical hypothyroidism in patients with type 2 diabetes mellitus. Korean J Intern Med. 2016;31(4): 703-11.

49. Qi Q, Zhang QM, Li CJ, Dong RN, Li JJ, Shi JY, et al. Association of thyroid-stimulating hormone levels with microvascular complications in type 2 diabetes patients. Med Sci Monit. 2017;23: 2715-20.

50. Cappola AR, Fried LP, Arnold AM, Danese MD, Kuller LH, Burke GL, et al. Thyroid status, cardiovascular risk, and mortality in older adults. JAMA. 2006;295(9): 1033-41. 
51. Mohamed GA, Elsayed AM. Subclinical hypothyroidism ups the risk of vascular complications in type 2 diabetes. Alexandria Journal of Medicine. 2017;53(3): 285-8.

52. Jia F, Tian J, Deng F, Yang G, Long M, Cheng W, et al. Subclinical hypothyroidism and the associations with macrovascular complications and chronic kidney disease in patients with type 2 diabetes. Diabet Med. 2015;32(8): 1097-103.

53. El-Eshmawy MM, Abd El-Hafez HA, El Shabrawy WO, Abdel Aal IA. Response: subclinical hypothyroidism is independently associated with microalbuminuria in a cohort of prediabetic egyptian adults (diabetes metab j 2013;37:450-7). Diabetes Metab J. 2014;38(1): 85-6.

54. Chubb SA, Davis WA, Inman Z, Davis TM. Prevalence and progression of subclinical hypothyroidism in women with type 2 diabetes: the Fremantle Diabetes Study. Clin Endocrinol (Oxf). 2005;62(4): 480-6.

55. Bos MM, Smit RAJ, Trompet S, van Heemst D, Noordam R. Thyroid Signaling, Insulin Resistance, and 2 Diabetes Mellitus: A Mendelian Randomization Study. J Clin Endocrinol Metab. 2017;102(6): 1960-70.

56. Buscemi S, Massenti FM, Vasto S, Galvano F, Buscemi C, Corleo D, et al. Association of obesity and diabetes with thyroid nodules. Endocrine. 2018;60(2): 339-47.

57. Iwen KA, Schroder E, Brabant G. Thyroid hormones and the metabolic syndrome. Eur Thyroid J. 2013;2(2): 8392.

58. Anil C, Akkurt A, Ayturk S, Kut A, Gursoy A. Impaired glucose metabolism is a risk factor for increased thyroid volume and nodule prevalence in a mild-to-moderate iodine deficient area. Metabolism. 2013;62(7): 970-5.

59. Barmpari ME, Kokkorou M, Micheli A, Alexiou I, Spanou E, Noutsou M, et al. Thyroid dysfunction among Greek patients with type 1 and type 2 diabetes mellitus as a disregarded comorbidity. J Diabetes Res. 2017;2017: 6505814.
60. Yasar HY, Ertugrul O, Ertugrul B, Ertugrul D, Sahin M. Insulin resistance in nodular thyroid disease. Endocr Res. 2011;36(4): 167-74.

61. Li H, Qian J. Association of diabetes mellitus with thyroid cancer risk: A meta-analysis of cohort studies. Medicine (Baltimore). 2017;96(47): e8230.

62. Xing M. Molecular pathogenesis and mechanisms of thyroid cancer. Nat Rev Cancer. 2013;13(3): 184-99.

63. Hu N, Li ZM, Liu JF, Zhang ZZ, Wang LS. An overall and dose-response meta-analysis for thyrotropin and thyroid cancer risk by histological type. Oncotarget. 2016;7(30): 47750-9.

64. Radisauskas R, Kuzmickiene I, Milinaviciene E, Everatt R. Hypertension, serum lipids and cancer risk: A review of epidemiological evidence. Medicina (Kaunas). 2016;52(2): 89-98.

65. Sun W, Lan X, Zhang H, Dong W, Wang Z, He L, et al. Risk factors for central lymph node metastasis in CNO papillary thyroid carcinoma: A systematic review and metaanalysis. PLoS One. 2015;10(10): e0139021.

66. LoSF, Chang SN, Muo CH, ChenSY, LiaoFY, DeeSW, et al. Modest increase in risk of specific types of cancer types in type 2 diabetes mellitus patients. Int $\mathrm{J}$ Cancer. 2013;132(1): 182-8

67. Bener A, Ozdenkaya Y, Al-Hamaq A, Barisik CC, Ozturk M. Low vitamin D deficiency associated with thyroid disease among type 2 diabetic mellitus patients. J Clin Med Res. 2018;10(9): 707-14.

68. Seo YG, Choi HC, An AR, Park DJ, Park YJ, Lee KE, et al. The association between type 2 diabetes mellitus and thyroid cancer. J Diabetes Res. 2017;2017: 5850879.

69. Pappa T, Alevizaki M. Metformin and thyroid: an update. Eur Thyroid J. 2013;2(1): 22-8.

70. Diez JJ, Iglesias P. An analysis of the relative risk for goitre in euthyroid patients with type 2 diabetes. Clin Endocrinol (Oxf). 2014;80(3): 356-61. 